\title{
Existing ecological theory applies to urban environments
}

\author{
Kirsten M. Parris ${ }^{1}$ (D)
}

Received: 5 January 2018 / Revised: 16 April 2018 / Accepted: 21 May 2018 / Published online: 14 June 2018

(c) The Author(s) 2018

\begin{abstract}
There is a prominent view within urban ecology that existing ecological theory is insufficient to understand the ecology of urban environments. However, many ecological theories, hypotheses and paradigms have been shown to apply to cities just as they do to other types of ecosystems. Here, I identify 16 ecological theories that have been applied to urban environments, with examples. I also illustrate the utility of metapopulation theory in cities with a case study on pond-breeding frogs in Melbourne, Australia.
\end{abstract}

Keywords Amphibians $\cdot$ Cities $\cdot$ Frogs $\cdot$ Urban ecology $\cdot$ Metapopulation theory

\section{Introduction}

A prominent school of thought within urban ecology holds that existing ecological theory is insufficient to understand the ecology of cities, where natural systems and human systems intersect (e.g., Alberti 2008; McPhearson et al. 2016). It has been proposed that urban ecosystems are more complex than other types of ecosystems because of their dynamism, their heterogeneity (across multiple spatial and temporal scales), their nonlinearity, the presence of social-biophysical feedbacks in cities, and the varied actions of thousands or millions of resident humans (Andersson 2006; Alberti 2008; Pickett et al. 2008; Qureshi et al. 2014). However, many other ecosystems are dynamic and heterogeneous, with various properties and transitional states that do not follow linear trajectories (e.g., Levin 1998; Anand et al. 2010). The complexity of multiple variables operating simultaneously across diverse spatial and temporal scales can be observed in a range of terrestrial, freshwater and marine ecosystems (e.g., Boit et al. 2012; Bozec et al. 2013; Laurance et al. 2014). Further, every ecosystem on Earth is now influenced in some way by the actions of humans, even if these actions are distant in space or time (e.g., Jambeck et al. 2015; Obrist et al. 2017).

Kirsten M. Parris

k.parris@unimelb.edu.au

1 School of Ecosystem and Forest Sciences, The University of Melbourne, Parkville, VIC 3010, Australia
I have previously argued that urban ecosystems, while displaying certain unique properties, do not have a unique ecology; that the apparent novelty of urban ecosystems does not translate into the need for a novel ecological theory to understand their structure and function (Parris 2016; also see Niemelä 1999; Catterall 2009; Faeth et al. 2011). For example, population dynamics in urban environments are governed by the same processes of birth, death, immigration and emigration as populations in other types of environments, while ecological communities in cities are shaped by the same processes of selection, dispersal, ecological drift and evolutionary diversification (Vellend 2010) that operate in woodlands, grasslands, lakes, estuaries and oceans. Despite the disruptions caused by the construction and operation of infrastructure such as houses, factories, roads, pavements, street lights and stormwater drains, urban ecosystems still function to cycle carbon, water and nutrients, and to provide services such as primary production, absorption of atmospheric pollutants, shading, cooling and the treatment of waste products (Parris 2016). To support this argument, I highlight here a range of ecological theories known to apply to urban environments. I also illustrate the utility of metapopulation theory in cities with a case study on pond-breeding frogs in Melbourne, Australia. 


\section{Ecological theories, hypotheses and paradigms}

A wide diversity of ecological theories, hypotheses and paradigms have been shown to apply to urban ecosystems (Table 1). These include niche theory and its many applications [such as species distribution models, trait-based analyses and studies of the temporal or spatial partitioning of resources within an ecological community (Parris 2016)]; the gradient paradigm of Whittaker (1967) in its manifestation as the urban-rural gradient of McDonnell and Pickett (1990); and the theory of landscape ecology including the concepts of habitat fragmentation, habitat isolation, and the patch-matrix model identifying areas of habitat and non-habitat in a landscape. Metapopulation and metacommunity theory, neutral theory, ecological trap theory and predator-prey dynamics, as well as behavioural ecology theories such as the acoustic adaptation hypothesis and optimal foraging theory, also have demonstrated utility in urban environments (Table 1). For example, a series of studies in Melbourne, Australia has applied the gradient paradigm, niche theory, metapopulation theory, metacommunity theory, landscape theory, the acoustic adaptation hypothesis, predator-prey relationships and the epidemiology of wildlife diseases to understand the ecology of pond-breeding frogs across the city (Parris 2006; Parris et al. 2009; Hamer and Parris 2011, 2013; Heard et al. 2013, 2015).

Table 1 A selection of ecological theories, paradigms and hypotheses that have been applied to urban environments, with some examples; please note that this list is not exhaustive

\begin{tabular}{|c|c|c|}
\hline Theory and key reference(s) & Study system & References \\
\hline Acoustic adaptation hypothesis (Morton 1975) & Birds, frogs, insects & $\begin{array}{l}\text { Brumm and Slabbekoorn (2005), Parris et al. } \\
\text { (2009) and Lampe et al. (2014) }\end{array}$ \\
\hline $\begin{array}{l}\text { Ecological trap theory (Dwernychuk and Boag } \\
\text { 1972) }\end{array}$ & Aquatic insects, urban wetlands & Horváth et al. (2009) and Hale et al. (2015) \\
\hline $\begin{array}{l}\text { Host-pathogen dynamics in a metapopulation } \\
\text { (Thrall and Burdon 1997) }\end{array}$ & Amphibians and chytridiomycosis & Heard et al. $(2014,2015)$ \\
\hline $\begin{array}{l}\text { Food webs/trophic dynamics (Hairston et al. } \\
\text { 1960) }\end{array}$ & Phoenix, Arizona; Sunshine Coast, Australia & Faeth et al. (2005) and Huijbers et al. (2013) \\
\hline $\begin{array}{l}\text { General theory of ecological communities } \\
\text { (Vellend 2010) }\end{array}$ & Microbes in wastewater & Nemergut et al. (2013) \\
\hline Gradient paradigm (Whittaker 1967) & Fungi, plants, birds, mammals, fish, insects & $\begin{array}{l}\text { McDonnell and Pickett (1990), Ishitani et al. } \\
\text { (2003) and McDonnell and Hahs (2008) }\end{array}$ \\
\hline $\begin{array}{l}\text { Intermediate disturbance hypothesis (Connell } \\
\text { 1978) }\end{array}$ & Birds, butterflies, plants, millipedes & $\begin{array}{l}\text { Blair (1996), McKinney (2008) and Bogyó } \\
\text { et al. (2015) }\end{array}$ \\
\hline $\begin{array}{l}\text { Interspecific (resource) competition (Tansley } \\
\text { 1917) }\end{array}$ & Birds, mosquitoes & Shochat et al. (2010) and Rochlin et al. (2013) \\
\hline $\begin{array}{l}\text { Landscape theory (Naveh and Lieberman } \\
\text { 1984) }\end{array}$ & Urban landscapes, grasslands, insects & $\begin{array}{l}\text { Luck and Wu (2002), Williams et al. (2005) and } \\
\text { Muñoz et al. (2015) }\end{array}$ \\
\hline Mesopredator release (Soulé et al. 1988) & $\begin{array}{l}\text { Coastal California, urban and peri-urban } \\
\text { parks in Virginia }\end{array}$ & Lewis et al. (1999) and Chupp et al. (2013) \\
\hline Metapopulation theory (Levins 1969) & Reptiles, amphibians & $\begin{array}{l}\text { Mollov and Volkonova (2009) and Heard et al. } \\
\text { (2013) }\end{array}$ \\
\hline $\begin{array}{l}\text { Metacommunity theory (Gilpin and Hanski } \\
\text { 1991; Leibold et al. 2004) }\end{array}$ & Amphibians, reptiles, aquatic invertebrates & Parris (2006) and Johnson et al. (2013) \\
\hline $\begin{array}{l}\text { Neutral theory of biodiversity and biogeogra- } \\
\text { phy (Hubbell 2001) }\end{array}$ & Birds & Sol et al. (2014) \\
\hline $\begin{array}{l}\text { Niche theory (Grinnell 1917; Hutchinson } \\
\text { 1957) }\end{array}$ & $\begin{array}{l}\text { Molluscs, plants, bats, reptiles, arthropods, } \\
\text { amphibians }\end{array}$ & $\begin{array}{l}\text { Baur and Baur (1993), Parris and Hazell (2005), } \\
\text { Armstrong (2009), Duncan et al. (2011) and } \\
\text { Wilson et al. (2013) }\end{array}$ \\
\hline Optimal foraging theory (Charnov 1976) & Squirrels, birds, lizards & $\begin{array}{l}\text { Bowers and Breland (1996), Shochat et al. } \\
\text { (2004) and Chejanovski et al. (2017) }\end{array}$ \\
\hline $\begin{array}{l}\text { Predator-prey dynamics (Lotka 1925; Volterra } \\
\text { 1926) }\end{array}$ & Birds and nest predators, tadpoles and fish & $\begin{array}{l}\text { Rodewald et al. (2011) and Hamer and Parris } \\
\text { (2013) }\end{array}$ \\
\hline
\end{tabular}




\section{Case study: pond-breeding frogs in Melbourne, Australia}

Here, I assess the relative influence of metapopulation processes and local habitat features on the persistence of four species of frogs in 104 ponds across the Melbourne metropolitan area. A metapopulation can be defined as a group of discrete populations, each occupying a separate patch of habitat, but with some level of dispersal between them. Over time, each patch of habitat may be occupied or unoccupied, as existing populations go locally extinct and empty patches are colonized by individuals that establish new populations; these changes are known as metapopulation dynamics (Hanski 1994a, b). Metapopulation theory (Levins 1969) proposes that small patches of habitat are less likely to support a population than large patches because of a higher probability of local extinction, while isolated patches are less likely to support a population than patches close to other suitable habitat because of a lower probability of colonization (immigration) from another patch (Hanski 1994a, 1999). Thus, the size and connectedness of habitat patches are important drivers of metapopulation dynamics. However, environmental conditions within each patch also play a role in the persistence of populations and the likelihood of colonization, as determined by the ecological niche and resource requirements of the species in question (Hanski 1999).

In this case study, I consider each pond to be a habitat patch which at any one time may or may not support a population of each target frog species. Using logistic regression modeling in a Bayesian framework, I assess the relative importance of pond size and connectedness (as proxies for metapopulation processes) and certain habitat characteristics of each pond (as indicators of speciesenvironment or niche relationships) for the occupancy of a pond by each species. Degradation of aquatic habitats with urbanization may lead to the loss or inaccessibility of key resources for wildlife (Parris 2016); for example, urban ponds may be confined within ornamental walls rather than a gently sloping bank, and may have altered or reduced vegetation cover. The relative importance of pond size and connectedness versus local habitat features at a pond is therefore a key question for understanding the ecology of pond-breeding amphibians in cities, but also for identifying the best options for their conservation management.

\section{Methods}

\section{Study area}

Melbourne is Australia's second-largest city, supporting a population of approximately 4.5 million people. It has a temperate climate with a mean annual maximum temperature of $19.9^{\circ} \mathrm{C}$ and a mean annual precipitation of $648 \mathrm{~mm}$, distributed evenly throughout the year (Bureau of Meteorology 2017). Fourteen species of frogs inhabit the Greater Melbourne area, and ten of these are known to breed in lentic aquatic habitats such as ponds, lakes and dams (Anstis 2013).

\section{Survey sites}

I selected 104 sites at lentic water bodies (ponds) in public parks and gardens, from the center of the city to its rural fringe along an informal urban-rural gradient (Fig. 1). Sites were stratified according to pond size (two classes, $<200$ and $\geq 200 \mathrm{~m}^{2}$ ) and the presence or absence of a vertical pond wall. See Parris (2006) for more information on site selection. Ponds ranged in size from 2 to $81,239 \mathrm{~m}^{2}$, with a mean size of $467 \mathrm{~m}^{2}$. The shortest distance between a pond and its nearest neighbor was $3 \mathrm{~m}$ and the longest was $12 \mathrm{~km}$, with a mean of $514 \mathrm{~m}$. I measured the area of small ponds in the field using a $25-\mathrm{m}$ tape measure; larger ponds were measured using satellite imagery in ArcGIS.

The connectedness of a habitat patch can be measured in a variety of ways; I used the number of ponds within a $500-\mathrm{m}$ radius of the target pond that were occupied by the species in question, excluding ponds that were isolated by a major road. This variable considers the number of other ponds supporting an extant population within dispersal distance of the target pond, rather than just the number or area of ponds within this distance. The latter two measures do not account for the habitat suitability of nearby ponds or their occupancy by the species in question, both of which are important considerations in metapopulation ecology (Heard et al. 2013). Only nearby ponds supporting extant populations can act as a source of immigrants to colonize the target pond following local extinction or to support a declining population (Hanski 1994b). There is little information on dispersal distances of the frog species in this study, but the smallest species (the common eastern froglet Crinia signifera) is known to disperse up to $500 \mathrm{~m}$ from ponds in a forested landscape (Lauck 2005). It is therefore likely that all four species can travel at least this distance if they are unhindered by substantial barriers in the urban landscape.

During habitat surveys at each site, I observed the presence or absence of a vertical pond wall, with a wall defined 


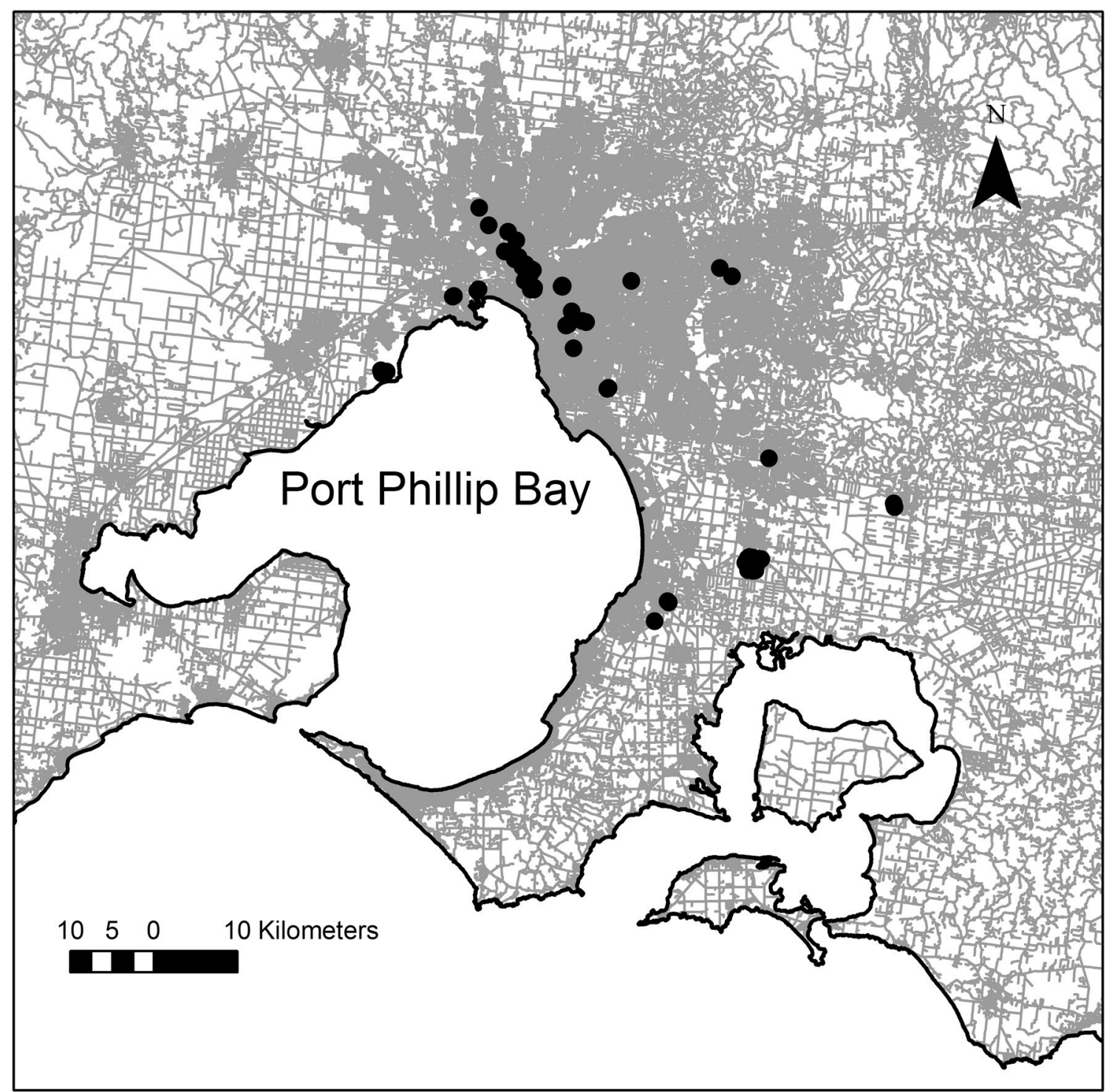

Fig. 1 Map of Greater Melbourne showing the location of 104 ponds included in the study (black circles). Roads (grey lines) indicate the density of urban development across the region, while the Central Business District of the city is indicated by the black triangle

as a vertical drop from the pond bank to the surface of the water. Such walls are commonly constructed of stone, concrete or wood as an ornamental edging around ponds in urban parks and gardens (Parris 2006). I also measured the proportion of the pond area covered by emergent vegetation and submerged vegetation, plus the proportion of the pond edge that supported fringing vegetation other than short, mown grass. I then summed these values to give the total vegetation at a pond, with a maximum possible value of 3 .

\section{Frog surveys}

I surveyed each site for frogs three times over two breeding seasons in spring-summer (September 2000-January 2001, and September-October 2001) using nocturnal searches. I recorded weather conditions during each survey, including dry- and wet-bulb temperature, wind speed, cloud cover and time since rain. Given the variable activity and thus detectability of frogs in the study area, three surveys were required to be confident of detecting the species present at a pond (Canessa et al. 2012). Nocturnal searches involved two people listening for the advertisement calls of male frogs at a site for $5 \mathrm{~min}$, then searching the pond and surrounding banks and vegetation with spotlights and head 
lamps for a minimum of $5 \mathrm{~min}$. The time spent searching was proportional to the size of the pond, with $5 \mathrm{~min}$ of searching added for each $20 \mathrm{~m}$ of pond perimeter. When necessary for identification, frogs were caught by hand then released unharmed at the point of capture.

\section{Data analysis}

I assessed the influence of four explanatory variables on the probability of occurrence of each of the target frog species at a pond using Bayesian logistic regression with uninformative priors in OpenBUGS 3.2.3 (Lunn et al. 2009). These variables were log (pond size) in $\mathrm{m}^{2}$ and pond connectedness (as proxies for metapopulation processes), plus the total vegetation at a pond and the presence or absence of a vertical pond wall (as indicators of species-environment or niche relationships). Pond vegetation provides important habitat for frogs, including shelter from weather and predators, calling sites for male frogs and attachment sites for egg masses. A vertical pond wall may limit use of a pond by ground-dwelling frogs that cannot climb vertical surfaces, as metamorphosing frogs cannot escape the water, become trapped in the pond and drown (Parris 2006).

I estimated the combined effect of the first two variables across their range of measured values when the second two were held constant at their mean (the metapopulation effect), and vice versa (the niche effect), to indicate whether metapopulation processes or local habitat features had the greatest influence on the probability of persistence of each frog species. I centered all explanatory variables (the centered value is the measured value of the variable minus its mean over all sites) to help reduce autocorrelation between successive samples obtained from the Monte Carlo Markov chain algorithm in OpenBUGS, and ran three chains for each model to check for convergence. For each chain, I generated 100,000 samples from the posterior distribution, thinned to one in every ten samples, after discarding the initial 150,000 samples as a burn-in. I calculated the mean and SD of the model coefficients, along with the 2.5th and 97.5th percentiles of the distribution which I used to represent a 95\% credible interval (the Bayesian analogue of a $95 \%$ confidence interval). If working within the null hypothesis significance testing framework, a credible interval that does not encompass 0 would indicate that a null hypothesis of no effect could be rejected at $\alpha=0.05$ (Cumming and Finch 2001).

\section{Results}

I detected nine species of frogs during the study, but only had sufficient records to model four of these: the common eastern froglet $C$. signifera, the striped marsh frog

Table 3 Coefficients (mean, SD, and 2.5th and 97.5th percentiles) of the explanatory variables included in the logistic regression model of the probability of occurrence of the striped marsh frog Limnodynastes peronii

\begin{tabular}{lcccc}
\hline Variable & Mean & SD & $2.5 \%$ & $97.5 \%$ \\
\hline Intercept & -1.508 & 0.3479 & -2.239 & -0.8763 \\
Pond size & 0.431 & 0.3237 & -0.1797 & 1.089 \\
Pond connectedness & 0.4324 & 0.1376 & 0.174 & 0.7138 \\
Total vegetation & 1.185 & 0.5666 & 0.109 & 2.334 \\
Vertical wall & -0.8875 & 0.8321 & -2.56 & 0.7193 \\
Metapopulation effect & 0.7566 & 0.1999 & 0.233 & 0.9789 \\
Niche effect & 0.4817 & 0.1536 & 0.1675 & 0.7589 \\
\hline
\end{tabular}

The metapopulation effect is the combined effect of pond size and pond connectedness across their range of measured values when vegetation at a pond and the presence/absence of a vertical pond wall are held constant at their mean; the niche effect is the opposite
Table 2 Coefficients (mean, SD, and 2.5th and 97.5th percentiles) of the explanatory variables included in the logistic regression model of the probability of occurrence of the common eastern froglet Crinia signifera

\begin{tabular}{lclcl}
\hline Variable & Mean & SD & \multicolumn{1}{l}{$2.5 \%$} & $97.5 \%$ \\
\hline Intercept & -0.01387 & 0.4995 & -1.009 & 0.9623 \\
Pond size & 1.193 & 0.4626 & 0.3622 & 2.178 \\
Pond connectedness & 0.5593 & 0.2121 & 0.2204 & 1.045 \\
Total vegetation & 0.8598 & 0.7022 & -0.4847 & 2.278 \\
Metapopulation effect & 0.9511 & 0.06455 & 0.7674 & 0.9989 \\
Niche effect & 0.693 & 0.1416 & 0.3786 & 0.916 \\
\hline
\end{tabular}

Note that this species never occurred at a pond with a vertical wall. The metapopulation effect is the combined effect of pond size and pond connectedness across their range of measured values when vegetation at a pond is held constant at its mean; the niche effect is the opposite
Table 4 Coefficients (mean, SD, and 2.5th and 97.5th percentiles) of the explanatory variables included in the logistic regression model of the probability of occurrence of the spotted marsh frog Limnodynastes tasmaniensis

\begin{tabular}{lclrc}
\hline Variable & Mean & SD & \multicolumn{1}{l}{$2.5 \%$} & $97.5 \%$ \\
\hline Intercept & -2.751 & 0.7998 & -4.485 & -1.356 \\
Pond size & 1.768 & 0.5826 & 0.7335 & 3.015 \\
Pond connectedness & 0.7229 & 0.2458 & 0.2758 & 1.243 \\
Total vegetation & 2.072 & 0.8112 & 0.5916 & 3.773 \\
Metapopulation effect & 0.9765 & 0.1612 & 0.8641 & 0.9997 \\
Niche effect & 0.3865 & 0.04108 & 0.1101 & 0.7175 \\
\hline
\end{tabular}

Note that this species never occurred at a pond with a vertical wall. The metapopulation effect is the combined effect of pond size and pond connectedness across their range of measured values when vegetation at a pond is held constant at its mean; the niche effect is the opposite 
Table 5 Coefficients (mean, SD, and 2.5th and 97.5th percentiles) of the explanatory variables included in the logistic regression model of the probability of occurrence of the southern brown tree frog Litoria ewingii

\begin{tabular}{lllcl}
\hline Variable & Mean & SD & $2.5 \%$ & $97.5 \%$ \\
\hline Intercept & 0.09157 & 0.2216 & -0.3436 & 0.5276 \\
Pond size & 0.7428 & 0.2458 & 0.2816 & 1.244 \\
Pond connectedness & 0.2845 & 0.09371 & 0.1078 & 0.475 \\
Total vegetation & 0.4877 & 0.4266 & -0.3441 & 1.334 \\
Vertical wall & 1.065 & 0.5974 & -0.07399 & 2.27 \\
Metapopulation effect & 0.8589 & 0.09394 & 0.6174 & 0.9725 \\
Niche effect & 0.4315 & 0.234 & -0.09225 & 0.8052 \\
\hline
\end{tabular}

The metapopulation effect is the combined effect of pond size and pond connectedness across their range of measured values when vegetation at a pond and the presence/absence of a vertical pond wall are held constant at their mean; the niche effect is the opposite

Limnodynastes peronii, the spotted marsh frog Limnodynastes tasmaniensis and the southern brown tree frog Litoria ewingii, which were detected at 39, 30, 25 and 54 of the 104 sites, respectively. Pond area and connectedness (as measured by the number of ponds within a 500-m radius that were occupied by the species in question) were predicted to have a positive effect on the probability of occurrence of all four species of frogs (Tables 2, 3, 4, 5), although the credible interval for the effect of pond size on $L$. peronii encompassed zero, indicating some uncertainty about this relationship. Total vegetation at a pond also had a positive effect on the probability of occurrence of all four species (with some uncertainty for $C$. signifera and $L$. ewingii), but the presence of a vertical pond wall affected different species in different ways. C. signifera and L. tasmaniensis were never detected at a pond with a vertical wall. However, Litoria ewingii, a tree frog that can climb vertical surfaces, was more likely to be present at ponds with a vertical wall (Table 5), while Limnodynastes peronii showed the opposite trend (Table 3).

Metapopulation processes (as measured by pond size and connectedness) and niche or species-environment relationships (as measured by local habitat variables) had an important effect on the probability of occurrence of each species, but in all cases the effect of metapopulation processes was larger. For example, the difference in the probability of occurrence of L. tasmaniensis between the ponds with the best and worst metapopulation conditions (at a pond without a vertical wall, with total vegetation held constant at its mean) - the metapopulation effect-was 0.98, while the difference in the probability of occurrence between the ponds with the best and worst habitat conditions (with pond area and connectedness held constant at their mean) - the niche effect-was 0.39 (Table 4 ). In the case of $L$. peronii, the metapopulation and niche effects were more similar; the difference in the probability of occurrence between the ponds with the best and worst metapopulation conditions (with total vegetation and presence of a vertical wall held constant at their mean) was 0.76 , while the difference in the probability of occurrence between the ponds with the best and worst habitat conditions (with pond area and connectedness held constant at their mean) was 0.48 (Table 3).

\section{Discussion}

Results of this study indicate that pond size and connectedness had substantial positive effects on the probability of occurrence of all four species of frog. This provides support for the applicability of metapopulation theory in this study system; larger ponds are more likely to be occupied because of a lower probability of local extinction, while more connected ponds are likely to receive more immigrants to bolster an existing population or recolonize a habitat patch following a local extinction (Hanski 1994a). The cover of vegetation in and around a pond plus the presence or absence of a vertical wall also had important effects on the probability of occurrence of the four frog species. All species were more likely to occur at ponds with more vegetation. For adult frogs, vegetation in and around a pond provides important shelter from predators, calling sites for males of all species and attachment sites for the egg masses of $C$. signifera and $L$. ewingii (Anstis 2013). Submerged vegetation also provides tadpoles with shelter from introduced fish and other predators, mediating predation risk in urban ponds (Hamer and Parris 2013). The three ground-dwelling species (C. signifera, L. tasmaniensis and L. peronii) responded negatively to pond walls, to the extent that the first two of these were never detected at a walled pond. In contrast, the tree frog L. ewingii, an able climber, was more likely to be detected at ponds with vertical walls. These associations with local habitat characteristics indicate that niche or species-environment relationships are also important in this study system.

Insights from this study can be applied to the conservation management of urban amphibians in Melbourne and beyond. While substantially increasing the size of ponds may be impractical, measures to (1) increase connectivity between ponds (such as the construction of new, suitable ponds within $500 \mathrm{~m}$ of existing occupied ponds) and/or (2) reduce barriers to dispersal across the urban landscape could support the persistence of frog metapopulations. Increasing vegetation cover in and around ponds and/or removing vertical walls could also benefit some species. The contention that we must wait for a new theory of urban ecology to understand urban ecosystems may hinder practical conservation actions in cities. In contrast, recognizing the applicability of existing theory allows us to move quickly to design better urban environments for both biodiversity and people, 
and to manage existing urban environments to improve their suitability for and utilization by frogs and other wildlife.

Acknowledgments I thank Michael McCarthy, Sarah Bekessy, Tom Browning, Jeannie Campbell, Terry Coates, Alexander Dalton, Lauren Edwards, Jane Elith, Amy Hahs, Michael Harper, Mark McDonnell, Nick O'Brien, Jenny Porter, Rodney van der Ree, Emma Seager, James Seager, Ollie Sherlock, Nick Williams, Brendan Wintle and Cassie Wright for assistance with fieldwork. I also thank Michael McCarthy for assistance with statistical analysis. This study was approved by the University of Melbourne Animal Experimentation Ethics Committee (register no. 00128), and conducted under research permit no. 10001422 issued by the Victorian Department of Natural Resources and Environment. It was supported by Australian Research Centre for Urban Ecology and the Australian Government through the National Environmental Science Program's Research Hub for Clean Air and Urban Landscapes.

Open Access This article is distributed under the terms of the Creative Commons Attribution 4.0 International License (http://creativeco mmons.org/licenses/by/4.0/), which permits unrestricted use, distribution, and reproduction in any medium, provided you give appropriate credit to the original author(s) and the source, provide a link to the Creative Commons license, and indicate if changes were made.

\section{References}

Alberti M (2008) Advances in urban ecology: integrating humans and ecological processes in urban ecosystems. Springer, New York

Anand M, Gonzales A, Guichard F et al (2010) Ecological systems as complex systems: challenges for an emerging science. Diversity 2:395-410

Andersson E (2006) Urban landscapes and sustainable cities. Ecol Soc $11: 34$

Anstis M (2013) Tadpoles and frogs of Australia. Reed New Holland, Sydney

Armstrong AJ (2009) Distribution and conservation of the coastal population of the black-headed dwarf chameleon Bradypodion melanocephalum in KwaZulu-Natal. Afr J Herpetol 58:85-97

Baur B, Baur A (1993) Climatic warming due to thermal-radiation from an urban area as possible cause for the local extinction of a land snail. J Appl Ecol 30:333-340

Blair RB (1996) Birds and butterflies along an urban gradient: surrogate taxa for assessing biodiversity? Ecol Appl 9:164-170

Bogyó D, Magura T, Simon E, Tóthmérész B (2015) Millipede (Diplopoda) assemblages alter drastically by urbanisation. Landsc Urban Plan 133:118-126

Boit A, Martinez ND, Williams RJ, Gaedke U (2012) Mechanistic theory and modelling of complex food-web dynamics in Lake Constance. Ecol Lett 15:594-602

Bowers MA, Breland B (1996) Foraging of gray squirrels on an urbanrural gradient: use of the GUD to assess anthropogenic impact. Ecol Appl 6:1135-1142

Bozec Y, Yakob L, Bejarano S, Mumby PJ (2013) Reciprocal facilitation and non-linearity maintain habitat engineering on coral reefs. Oikos 122:428-440

Brumm H, Slabbekoorn H (2005) Acoustic communication in noise. Adv Study Behav 35:151-209

Bureau of Meteorology (2017) Summary statistics. Melbourne Regional Office. http://www.bom.gov.au/climate/averages/table s/cw_086071.shtml
Canessa S, Heard GW, Parris KM, McCarthy MA (2012) Integrating variability in detection probabilities when designing wildlife surveys: a case study of amphibians from south-eastern Australia. Biodivers Conserv 21:729-744

Catterall CP (2009) Responses of faunal assemblages to urbanisation: global research paradigms and an avian case study. In: McDonnell MJ, Hahs AK, Brueste J (eds) Ecology of cities and towns: a comparative approach. Cambridge University Press, Cambridge, pp 129-155

Charnov EL (1976) Optimal foraging, the marginal value theorem. Theor Popul Biol 9:129-136

Chejanovski ZA, Avilés-Rodríguez KJ, Lapiedra O et al (2017) An experimental evaluation of foraging decisions in urban and natural forest populations of Anolis lizards. Urban Ecosyst 20:1011. https ://doi.org/10.1007/s11252-017-0654-5

Chupp AD, Roder AM, Battaglia LL, Pagels JF (2013) A case study of urban and peri-urban mammal communities: implications for the management of National Park Service areas. Northeast Nat 20:631-654

Connell JH (1978) Diversity in tropical rain forests and coral reefs. Science 199(4335):1302-1310

Cumming G, Finch S (2001) A primer on the understanding, use, and calculation of confidence intervals that are based on central and non-central distributions. Educ Psychol Meas 61:532-574

Duncan RP, Clemants SE, Corlett RT et al (2011) Plant traits and extinction in urban areas: a meta-analysis of 11 cities. Glob Ecol Biogeogr 20:509-519

Dwernychuk LW, Boag DA (1972) Ducks nesting in association with gulls-an ecological trap? Can J Zool 50:559-563

Faeth SH, Warren PS, Shochat E, Marussich WA (2005) Trophic dynamics in urban communities. Bioscience 55:399-407

Faeth SH, Bang C, Saari S (2011) Urban biodiversity: patterns and mechanisms. Ann NY Acad Sci 1223:69-81

Gilpin M, Hanski I (eds) (1991) Metapopulation dynamics. Academic, London

Grinnell J (1917) The niche-relationships of the California thrasher. Auk 34:427-433

Hairston NG, Smith FE, Slobodkin LB (1960) Community structure, population control, and competition. Am Nat 44:421-425

Hale R, Coleman R, Pettigrove V, Swearer SE (2015) Review: identifying, preventing and mitigating ecological traps to improve the management of urban aquatic ecosystems. J Appl Ecol 52:928-939

Hamer AJ, Parris KM (2011) Local and landscape determinants of amphibian communities in urban ponds. Ecol Appl 21:378-390

Hamer AJ, Parris KM (2013) Predation modifies larval amphibian communities in urban wetlands. Wetlands 33:641-652

Hanski I (1994a) A practical model of metapopulation dynamics. J Anim Ecol 63:151-162

Hanski I (1994b) Patch-occupancy dynamics in fragmented landscapes. Trees 9:131-135

Hanski I (1999) Metapopulation ecology. Oxford University Press, Oxford

Heard GW, McCarthy MA, Scroggie MP, Baumgartner JB, Parris KM (2013) A Bayesian model of metapopulation viability, with application to an endangered amphibian. Divers Distrib 19:555-566

Heard GW, Scroggie MP, Clemann N, Ramsey DSL (2014) Wetland characteristics influence disease risk for a threatened amphibian. Ecol Appl 24:650-662

Heard GW, Thomas CD, Hodgson JA et al (2015) Refugia and connectivity sustain amphibian metapopulations afflicted by disease. Ecol Lett 18:853-863

Horváth G, Kriska G, Malik P, Robertson B (2009) Polarized light pollution: a new kind of ecological photopollution. Front Ecol Environ 7:317-325 
Hubbell SP (2001) The unified neutral theory of biodiversity and biogeography. Princeton University Press, Princeton

Huijbers CM, Schlacher TA, Schoeman DS, Olds AD, Weston MA, Connolly RM (2013) Urbanisation alters processing of marine carrion on sandy beaches. Landsc Urban Plan 119:1-8

Hutchinson GE (1957) Cold spring harbor symposium on quantitative biology. Concluding Remarks 22:415-427

Ishitani M, Kotze J, Niemela J (2003) Changes in carabid beetle assemblages across an urban-rural gradient in Japan. Ecography 26:481-489

Jambeck JR, Geyer R, Wilcox C et al (2015) Plastic waste inputs from land into the ocean. Science 347(6223):768-771

Johnson PTJ, Hoverman JT, McKenzie VJ et al (2013) Urbanization and wetland communities: applying metacommunity theory to understanding the local and landscape effects. J Appl Ecol 50:34-42

Lampe U, Reinhold K, Schmoll T (2014) How grasshoppers respond to road noise: developmental plasticity and population differentiation in acoustic signalling. Funct Ecol 28:660-668

Lauck B (2005) The impact of recent logging and pond isolation on pond colonization by the frog Crinia signifera. Pac Conserv Biol 11:50-56

Laurance WF, Andrade AS, Magrach A et al (2014) Apparent environmental synergism drives the dynamics of Amazonian forest fragments. Ecology 95:3018-3026

Leibold MA, Holyoak M, Mouquet N et al (2004) The metacommunity concept: a framework for multi-scale community ecology. Ecol Lett 7:601-613

Levin SA (1998) Ecosystems and the biosphere as complex adaptive systems. Ecosystems 1:431-436

Levins R (1969) Some demographic and genetic consequences of environmental heterogeneity for biological control. Bull Entomol Soc Am 15:237-240

Lewis JC, Sallee KL, Golightly RT (1999) Introduction and range expansion of nonnative red foxes (Vulpes vulpes) in California. Am Midl Nat 142:372-381

Lotka AJ (1925) Elements of physical biology. Williams and Wilkins, Baltimore

Luck M, Wu J (2002) A gradient analysis of the landscape pattern of urbanization in the Phoenix metropolitan area of USA. Landsc Ecol 17:327-339

Lunn D, Spiegelhalter D, Thomas A, Best N (2009) The BUGS project: evolution, critique, and future directions. Stat Med 28:3049-3067

McDonnell MJ, Hahs AK (2008) The use of gradient analysis studies in advancing our understanding of the ecology of urbanizing landscapes: current status and future directions. Landsc Ecol 23:1143-1155

McDonnell MJ, Pickett STA (1990) Ecosystem structure and function along urban-rural gradients: an unexploited opportunity for ecology. Ecology 71:1232-1237

McKinney ML (2008) Effects of urbanization on species richness: a review of plants and animals. Urban Ecosyst 11:161-176

McPhearson T, Pickett STA, Grimm NB et al (2016) Advancing urban ecology toward a science of cities. Bioscience 66:198-212

Mollov IA, Volkonova MV (2009) Risks and opportunities of urbanization-structure of two populations of the Balkan wall lizard Podarcis tauricus (Pallas, 1814) in the city of Plovdiv. Ecol Balkanica 1:27-39

Morton ES (1975) Ecological sources of selection on avian sounds. Am Nat 109:17-34

Muñoz PT, Torres FP, Megías AG (2015) Effects of roads on insects: a review. Biodivers Conserv 24:659. https://doi.org/10.1007/s1053 1-014-0831-2

Naveh Z, Lieberman A (1984) Landscape ecology: theory and application. Springer, New York
Nemergut DR, Schmidt SK, Fukami T et al (2013) Patterns and processes of microbial community assembly. Microbiol Mol Biol Rev $77: 342-356$

Niemelä J (1999) Is there a need for a theory of urban ecology? Urban Ecosyst 3:57-65

Obrist D, Agnan Y, Jiskra M et al (2017) Tundra uptake of atmospheric elemental mercury drives Arctic mercury pollution. Nature 547:201-204

Parris KM (2006) Urban amphibian assemblages as metacommunities. J Anim Ecol 75:757-764

Parris KM (2016) Ecology of urban environments. Wiley Blackwell, Oxford

Parris KM, Hazell DL (2005) Biotic effects of climate change in urban environments: the case of the grey-headed flying-fox (Pteropus poliocephalus) in Melbourne, Australia. Biol Conserv 124:267-276

Parris KM, Velik-Lord M, North JMA (2009) Frogs call at a higher pitch in traffic noise. Ecol Soc 14:25

Pickett STA, Cadenasso ML, Grove JM et al (2008) Beyond urban legends: an emerging framework of urban ecology, as illustrated by the Baltimore Ecosystem Study. Bioscience 58:139-150

Qureshi S, Haase D, Coles R (2014) The Theorized Urban Gradient (TUG) method-a conceptual framework for socio-ecological sampling in complex urban agglomerations. Ecol Indic 36:100-110

Rochlin I, Gaugler R, Williges E, Farajollahi A (2013) The rise of the invasives and decline of the natives: insights revealed from adult populations of container-inhabiting Aedes mosquitoes (Diptera: Culicidae) in temperate North America. Biol Invasions 15:991-1003

Rodewald AD, Kearns LJ, Shustack DP (2011) Anthropogenic resource subsidies decouple predator-prey relationships. Ecol Appl 21:936-943

Shochat E, Lerman S, Katti M, Lewis D (2004) Linking optimal foraging behavior to bird community structure in an urban-desert landscape: field experiments with artificial food patches. Am Nat 164:232-243

Shochat E, Lerman SB, Anderies JM et al (2010) Invasion, competition, and biodiversity loss in urban ecosystems. Bioscience 60:199-208

Sol D, González-Lagos C, Moreira D et al (2014) Urbanisation tolerance and the loss of avian diversity. Ecol Lett 17:942-950

Soulé ME, Bolger DT, Alberts AC et al (1988) Reconstructing dynamics of rapid extinction of chaparral-requiring birds in urban habitat island. Conserv Biol 2:75-92

Tansley AG (1917) On competition between Galium saxatile L. (G. hercynium Weig.) and Galium sylvestre Poll. (G. asperum Schreb.) on different types of soil. J Ecol 5:173-179

Thrall PH, Burdon JJ (1997) Host-pathogen dynamics in a metapopulation context: the ecological and evolutionary consequences of being spatial. J Ecol 85:743-753

Vellend M (2010) Conceptual synthesis in community ecology. Quart Rev Biol 85:183-206

Volterra V (1926) Variazioni e fluttuazioni del numero d'individui in specie animali conviventi. Mem Acad Lincei Roma 2:31-113

Whittaker RH (1967) Gradient analysis of vegetation. Biol Rev 42:207-264

Williams NSG, McDonnell MJ, Seager EJ (2005) Factors influencing the loss of an endangered ecosystem in an urbanising landscape: a case study of native grasslands from Melbourne, Australia. Landsc Urban Plan 71:35-49

Wilson JN, Bekessy S, Parris KM et al (2013) Impacts of climate change and urban development on the spotted marsh frog (Limnodynastes tasmaniensis). Austral Ecol 38:11-22 